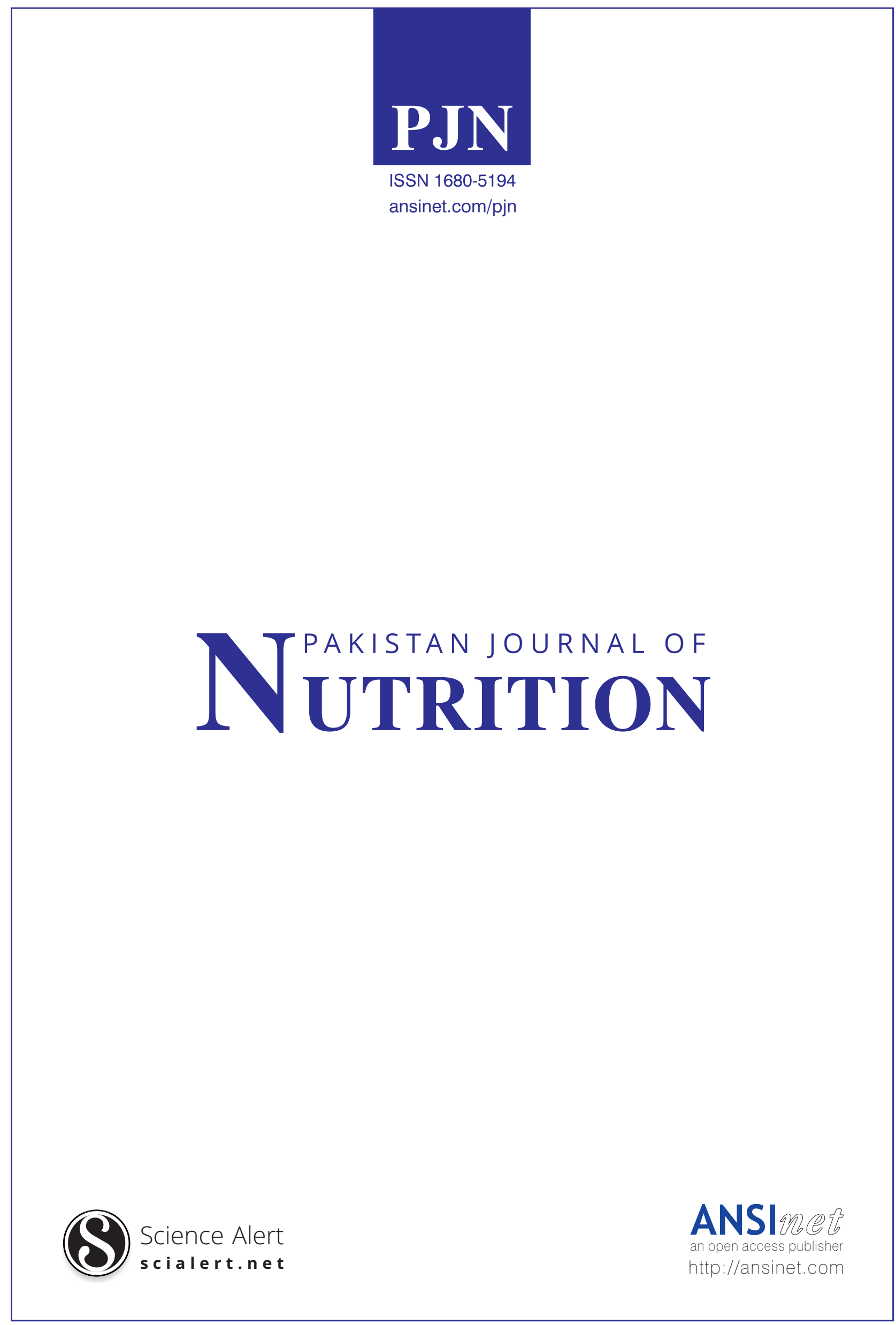




\title{
Effectiveness of Animations, Comic Strips and Booklets as Educational Media for Female Teens Concerning the First Thousand Days of Life
}

\author{
${ }^{1}$ Novriani Tarigan and ${ }^{2}$ Risma Dumiri Manurung \\ ${ }^{1}$ Department of Nutrition, Health Polytechnic Medan, North Sumatera, Indonesia \\ ${ }^{2}$ Departments of Nurse, Health Polytechnic Medan, North Sumatera, Indonesia
}

\section{Abstract}

Background and Objective: Preventative strategies and remedies for stunting must be accurately initiated. One of the strategies is to educate girls concerning the first 1000 days of life (FTDL). Such education could be delivered by various media. This study aimed to measure the effectiveness of animated books, comic strips and booklets as media to deliver nutritional education about the FTDL. Materials and Methods: A total of 45 respondents consisting of three groups of students from three private high schools in Lubuk Pakam were included. Each group received only one kind of media. The three types of media were designed by the researcher, with the assistance of specialists for the design of the first two types of media. All the media consisted of 4 series. Information pertaining to the respondents' characteristics were collected by the interviewer. There was also a pretest and post test given to the respondents to assess their knowledge and attitudes. The media intervention was conducted two times. Results: The difference in knowledge before and after the intervention was 8.53 on average. The averaged knowledge before and after the intervention in all the groups was analyzed by Wilcoxon statistics, with $p=0.001$, showing an increase in the respondents' knowledge and attitudes. The maximum average difference in the respondents' attitudes was observed in the Animation group. The Kruskal Wallis test revealed $(p=0.001)$ a significant difference in the knowledge and attitudes among the groups. The result of the knowledge/attitude N-Gain showed a higher effectiveness of animated books than that of comics and booklets. Conclusion: Animation media is more effective than comics and booklets for improving the knowledge and attitudes of female teens regarding the first 1000 days of life.

Key words: Animation media, comic strips, booklet, the first 1000 days of life, nutritional education

Citation: Novriani Tarigan and Risma Dumiri Manurung, 2020. Effectiveness of animations, comic strips and booklets as educational media for female teens concerning the first thousand days of life. Pak. J. Nutr., 19: 374-380.

Corresponding Author: Novriani Tarigan, Department of Nutrition, Health Polytechnic Medan, North Sumatera, Indonesia

Copyright: @ 2020 Novriani Tarigan and Risma Dumiri Manurung. This is an open access article distributed under the terms of the creative commons attribution License, which permits unrestricted use, distribution and reproduction in any medium, provided the original author and source are credited.

Competing Interest: The authors have declared that no competing interest exists. 


\section{INTRODUCTION}

The 2018 Global Nutrition Report has emphasized the high rate of bad nutrition. The cases of malnutrition in various forms remain high all over the world'. Basic Health Research (Riset Kesehatan Dasar) in Indonesia reported a prevalence of stunting of 36.8, 37.2 and 30.8\% in 2007, 2013 and 2018, respectively ${ }^{2}$. Stunting remains at a high level, although it seemed to decrease in North Sumatra Province, which ranked eighth in the prevalence of stunting in Indonesia ${ }^{3}$.

The World Health Organization has adopted the nutritional resolution on mother, infant and children that includes six global targets to reduce nutrition-related illness mainly during the critical period from conception to 24 month of age. The first target is to reduce the number of stunted children under 5 years of age by $40 \%$ by $2025^{4}$. Stunting, meaning short stature compared to that of peers, is a manifestation of failure to grow in infants under 11 months old and in children aged 12-59 months caused by a chronic lack of nutrition during the first 1000 days of life ${ }^{5,6}$. Consistent evidence shows that lack of exclusive breastfeeding during the first six months of life, low income, premature birth, short stature of the newborn baby, short stature of the mother and education, were the main causes of stunting in children in Indonesia.

We know that females under 54 years of age, $2.6 \%$ were married before 15 years of age and $23.9 \%$ were married between 15-19 years ofage ${ }^{7}$. People do not realize that lack of nutrition in children will cause future stunting and that preventative strategies and remedies for stunting can be initiated as early as possible by educating females under 19 years of age concerning first 1000 days of life.

The FTDL focused on two types of interventions: specific nutrition and sensitive nutrition intervention ${ }^{8}$. Early, specific nutrition intervention for teen females is likely helpful with more education. Nutritional education could utilize various media. Media is a possible means used to excite minds, feelings, interest and abilities or skills to drive the learning process ${ }^{9}$. In the last decade, visual narration, such as comics and animations, have been more popular tools used in science and communication education ${ }^{10}$ and are able to reach a wide range of people ${ }^{11}$. A study that compared comics and animation as tools for conveying medical information revealed that animated video (i.e., slide shows with voice-over narration) was more effective than comics and that both video and comics were better than plain text ${ }^{12}$. Various studies showed that booklets were able to add knowledge ${ }^{13-15}$. However, comics and animations have not been widely used as educational tools, especially concerning FTDL. This study aimed to measure the effectiveness of animations, comic strips and booklets as media to deliver nutritional education about the FTDL.

\section{MATERIALS AND METHODS}

This study was performed in three private high schools, namely, Dharma Bhakti, Nusantara and Serdang Murni, from January to October 2019. The samples population included 45 teen females from each school. This study was a quasiexperiment with a pretest-posttest control group design. The knowledge and attitudes of the respondents were measured before and after the intervention. Ethical approval for this study was provided by the Ethical Commission of Health Research of Medical Politeknik Medan by letter \#262/KEPK Poltekkes Kemenkes Medan, 2019. Informed consent was received from the respondents prior to study, as well.

This study was performed in two stages:

Stage 1:Preparation: Smartphone-based animations, comics and booklets were designed on theoretical view. The media contained 4 serial materials: (1) Definition of FTDL, (2) Balanced nutrition for pregnant women, (3) Balanced nutrition for 6-month-old infants, (4) Balanced nutrition for 6- to 24-month-old children and complementary food for breast milk. The visual design, characters and dialogues were created by researchers. The main characters were Tiur, avegetable vendor, Tiara, a midwife but et, a nutritionist and Rose, Susan and her mother-in-law, normal people. Comics were created with the assistance of professionals. The twominute animations were created with the assistance of a computer graphic technician using the same picture and players as in the comic strips filled in with voices. Voices were filled by dubbing the voices of the researchers, enumerators and assistance staff.

Stage 2: Intervention and data collection: The initial data (i.e., age, body weight/height, upper wrist circumference, parent's data, such as education, job, ethnic group) was collected by the questionnaire. The knowledge pretest consisted of 40 questions; the attitude pretest consisted of 25 questions. Both tests were performed by a questionnaire about the FTDL. The pretests were followed by two interventions that were performed in one week and with one idle week. The intervention was resumed and followed by one idle week. The animations intervention was conducted in Dharma Bhakti, the comic strip intervention in Nusantara and the booklet intervention in Serdang Murni. Each intervention was performed in one room. The animation group received 
the intervention via smartphone WhatsApp (WA) messenger. One comic strip was handed to each member of the comics group. These individuals were allowed to read the strips within 30 min then take the strip home. It was suggested to them that they read the strip again at home. One booklet was handed over each member of the booklet group. These individuals were allowed to read the booklet within $30 \mathrm{~min}$, take the booklet home and read it again at home. Following the intervention, a post test was performed to measure the knowledge and attitudes of the respondents toward the FTDL.

Data analysis: The pretest and post test questionnaires were evaluated. Each answer to a question indicating correct knowledge was given a value of 1 and an answer was given a value of 0 if the answer indicated incorrect knowledge. A supportive response on the attitude section was given a value of 1 , an on supportive response was given a value of 0 . Each respondent collected a score of pretest and post test of knowledge and attitude. The descriptive statistics of this study was presented as the Mean \pm Standard deviation of the knowledge and attitude scores of the female teens. Bivariate analysis to examine the hypothetical increase in the knowledge and attitude of all the intervention groups was conducted using Wilcoxon test, i.e., the data were not normally distributed. Then, the Kruskal-Wallis Test $(p<0.05)$ was used to analyze the statistical significance of the knowledge and attitudes between groups. Then, the gain score was calculated.

\section{RESULTS AND DISCUSSION}

The parents' characteristics are shown in Table 1.

Fifty percent of the parents of all the group members attended either high school or college. Greater than $50 \%$ of the fathers of the members of the animations group were entrepreneurs, traders and farmers. Most of mothers from all the groups were homemakers. Greater than $50 \%$ of the fathers and mothers of the members of the animation group were of

Table 1: Characteristics of the respondents' parent base in the animations, comic strips and booklet groups

\begin{tabular}{|c|c|c|c|c|c|c|c|}
\hline \multirow[b]{2}{*}{ Variables } & \multicolumn{2}{|c|}{ Animations group } & \multicolumn{2}{|c|}{ Comic strips group } & \multicolumn{2}{|c|}{ Booklet group } & \multirow[b]{2}{*}{$p$-value } \\
\hline & No. & Percentage & No. & Percentage & No. & Percentage & \\
\hline \multicolumn{8}{|l|}{ Father's education } \\
\hline Basic school & 2 & 4.5 & 4 & 8.9 & 1 & 2.20 & 0.850 \\
\hline Middle school & 4 & 8.9 & 4 & 8.9 & 3 & 6.70 & \\
\hline High school & 33 & 73.3 & 31 & 69.0 & 33 & 73.33 & \\
\hline College & 6 & 13.3 & 6 & 13.3 & 8 & 17.80 & \\
\hline \multicolumn{8}{|c|}{ Mother's education } \\
\hline Basic school & 5 & 11.1 & 3 & 6.7 & 1 & 2.20 & 0.091 \\
\hline Middle school & 8 & 17.8 & 8 & 17.8 & 1 & 2.20 & \\
\hline High school & 25 & 55.6 & 29 & 64.4 & 36 & 80.00 & \\
\hline College & 7 & 15.5 & 5 & 11.1 & 7 & 15.60 & \\
\hline \multicolumn{8}{|c|}{ Father's occupation } \\
\hline Civil servants & 3 & 6.7 & 8 & 17.8 & 4 & 8.90 & 0.044 \\
\hline Private employee & 4 & 8.9 & 2 & 4.6 & 5 & 11.10 & \\
\hline Entrepreneur & 23 & 51.1 & 17 & 37.8 & 13 & 28.90 & \\
\hline Trading/farmer & 3 & 6.7 & 10 & 22.2 & 15 & 33.30 & \\
\hline Others & 12 & 26.6 & 8 & 17.8 & 8 & 17.80 & \\
\hline \multicolumn{8}{|c|}{ Father's occupation } \\
\hline Civil servants & 2 & 4.5 & 6 & 13.3 & 7 & 15.60 & 0.016 \\
\hline Private employee & 2 & 4.5 & 1 & 2.2 & 3 & 6.60 & \\
\hline Entrepreneur & 11 & 24.4 & 2 & 4.6 & 5 & 11.10 & \\
\hline Trading/farmer & 3 & 6.6 & 3 & 6.6 & 7 & 15.60 & \\
\hline House mother & 27 & 60.0 & 32 & 71.1 & 19 & 42.20 & \\
\hline Others & 0 & 0 & 1 & 2.2 & 4 & 8.90 & \\
\hline \multicolumn{8}{|c|}{ Father's ethnic group } \\
\hline Batak & 13 & 28.9 & 21 & 46.7 & 42 & 93.30 & 0.001 \\
\hline Malayan & 3 & 6.7 & 2 & 4.5 & 3 & 6.70 & \\
\hline Java & 4 & 8.9 & 16 & 35.5 & 0 & 0.00 & \\
\hline Others & 25 & 55.5 & 6 & 13.3 & 0 & 0.00 & \\
\hline \multicolumn{8}{|c|}{ Mother's ethnic group } \\
\hline Batak & 17 & 37.8 & 19 & 42.2 & 42 & 93.30 & 0.001 \\
\hline Malayan & 1 & 2.2 & 1 & 2.2 & 3 & 6.70 & \\
\hline Java & 4 & 8.9 & 19 & 42.2 & 0 & 0.00 & \\
\hline Others & 23 & 51.1 & 6 & 13.4 & 0 & 0.00 & \\
\hline
\end{tabular}


Pak. J. Nutr., 19 (8): 374-380, 2020

Table 2: Respondent characteristics in the animations, comic strips and booklet groups

\begin{tabular}{|c|c|c|c|c|c|c|c|}
\hline \multirow[b]{2}{*}{ Variables } & \multicolumn{2}{|c|}{ Animations group } & \multicolumn{2}{|c|}{ Comic strips group } & \multicolumn{2}{|c|}{ Booklet group } & \multirow[b]{2}{*}{$p$-value } \\
\hline & Avg. & SD & Avg. & SD & Avg. & SD & \\
\hline Age (year) & 16.5 & 0.8 & 16.7 & 0.6 & 16.1 & 0.8 & 0.280 \\
\hline Body weight (kg) & 51.5 & 10.5 & 49.4 & 8.3 & 52.3 & 6.9 & 0.085 \\
\hline Height(cm) & 155.1 & 5.4 & 152.9 & 5.4 & 153.5 & 6.6 & 0.764 \\
\hline UAC (cm) & 23.2 & 3.5 & 24.8 & 2.9 & 25.9 & 2.3 & 0.120 \\
\hline $\mathrm{BMI}\left(\mathrm{kg} \mathrm{m}^{-2}\right)$ & 21.5 & 4.5 & 21.2 & 3.7 & 22.2 & 2.8 & 0.730 \\
\hline
\end{tabular}

Table 3: Average, standard deviation, minimum and maximum of respondents' knowledge

\begin{tabular}{|c|c|c|c|c|c|c|}
\hline \multirow[b]{2}{*}{ Knowledge } & \multicolumn{2}{|c|}{ Animations group } & \multicolumn{2}{|c|}{ Comic strips group } & \multicolumn{2}{|c|}{ Booklet group } \\
\hline & Before & After & Before & After & Before & After \\
\hline Average & 19.900 & 28.5 & 19.600 & 25.4 & 20.200 & 25.9 \\
\hline Standard deviation & 2.900 & 2.9 & 3.600 & 5.3 & 2.900 & 3.4 \\
\hline Minimum value & 13.000 & 21.0 & 11.000 & 12.0 & 13.000 & 19.0 \\
\hline Maximum value & 26.000 & 34.0 & 25.000 & 36.0 & 25.000 & 32.0 \\
\hline $\mathrm{N}$ & 45.000 & & 45.000 & & 45.000 & \\
\hline p value & 0.001 & & 0.001 & & 0.001 & \\
\hline Average difference & 8.500 & & 5.800 & & 5.700 & \\
\hline
\end{tabular}

Chinese and Indian descent. Most of the members of the comic strip group belonged to the Batak and Java ethnicity. Almost all of the fathers of the members of the booklet group were of Batak descent. The parents' educational levels in all the groups were similar. The occupations of the fathers and mothers of the members of the groups were different, as were their ethnicities $(p<0.005)$.

Respondents' characteristics: The respondent characteristics data (i.e., age, body weight/height, upper arm circumference and body mass index)were collected before the intervention (Table 2). A test of homogeneity on the variables demonstrated that the characteristics of all the groups were homogeneous ( $p>0.05$; Table 2 ).

The homogeneity of the characteristics of all the groups is mandatory for the experimental research. The homogeneity of the characteristic agrees with previous research ${ }^{16}$.

\section{Bivariate analysis of respondents' knowledge: Knowledge} is a result of knowing. Knowledge is achieved after one senses a certain object. The sensing processes are performed by human sensing organs by seeing, smelling and touching certain objects. Most of human knowledge is captured by the eyes and ears. The average, standard deviation and minimum and maximum of the respondent knowledge scores are shown in Table 3.

The average knowledge of the respondents before the animations intervention and comic strip intervention are almost same, namely, $19.9 \pm 2.9$ and $19.6 \pm 3.6$, respectively. The average knowledge before the booklet intervention was higher that is $20.2 \pm 2.9$. The average knowledge after the comic strip intervention and booklet intervention were almost same, namely, $25.4 \pm 5.3$ and $25.9 \pm 3.4$, respectively. The average knowledge after the animations intervention was $28.5 \pm 2.9$. The averaged difference in the highest animations intervention was 8.5 , followed by the comic strips group with 5.8 and the booklet group with 5.7.

This result revealed that nutritional education was successful in adding to the knowledge of the respondents in each group concerning the FTDL. The result of the Wilcoxon test showed that the average knowledge of the respondents in the intervened groups significantly increased, $p=0.001$ $(p<0.05)$. The increase in the knowledge of each group was not the same; the greatest increase was observed in the animations group.

In parallel with this study, interventions by short message service(SMS)and booklets concerning obesity in female teens have contributed a significant effect toward increasing the knowledge in each intervention group ${ }^{16}$. The results of a study concerning the effectiveness of videos and animations on mother's attitude and knowledge concerning balanced nutrition for infants revealed that animations were more effective ${ }^{17}$. A study on the effectiveness of videos and leaf lets concerning knowledge about anemia in female high school students of SMAN2 Ng aglik Sleman revealed that there was an increase in knowledge, which was proven by a posttest, in each group; it was concluded that videos were more effective than leaflets due to ease of access ${ }^{18}$.

A real practice will last long when it is grounded in knowledge. Therefore, it is important for respondents to acquire knowledge concerning the FTDL. Such knowledge has an important role in affecting the future nutrition-related attitudes of the respondents and their families. 
Bivariate analysis of respondents' attitudes: Attitude is a mental and neural condition that contributes to a response toward a certain object; attitude is organized by experiences and directly or indirectly affects a person's actions. Attitude is a readiness or willingness to act but is not an executor of a certain motive. Attitude is not an act or activity yet but a pred is position toward a certain attitude.

Table 4 shows the averages of the respondents' attitudes. The highest attitude was observed in the booklet group (17 \pm 2.6$)$ followed by that in the animations group (16.6 \pm 2.6$)$

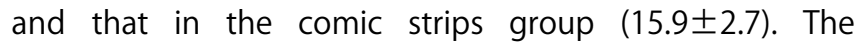
intervention that resulted in the greatest increase in the average respondents' attitude was the animations group (20.3 \pm 2.7$)$, followed by the booklet group $(20.1 \pm 2.3)$ and the comicstrips group (17.9 \pm 3.2$)$. This result showed that the average of the differences in the animations group was the highest (3.7) and that the lowest was that in the comic strips group (2.0). The result of the Wilcoxon statistics test revealed $(p=0.001)$ in all the groups, an increase in the respondents' attitudes concerning the FTDL.

The results of this study show that the highest score of the average respondents' attitudes concerning the FTDL before the intervention was achieved by the booklet group, followed by that in the animations group following the intervention.

Attitude is a readiness to react against a certain object when there is a stimulus demanding a response. Attitude is readiness or willingness to act but not an executor of a certain motive. Attitude is not an act or activity but a predisposition of certain attitude ${ }^{19}$. Attitude contains a moving power or motivation. Attitude is not merely a previously recorded collection but affects the respondents to support a certain matter or not or determines the respondents' choices, their aspirations, or their avoidances, especially concerning nutrition related FTDL.

Bivariate analysis of the respondents' knowledge and attitude: Table 5 shows that the average knowledge and attitudes of the animations group exhibited a higher increase compared to that in the rest of the groups. The results of the Kruskal Wallis test by $p=0.001(p<0.005)$, showed a significant difference in the knowledge and attitudes $\mathrm{n}$ all the groups.

In parallel with his study, $\mathrm{Kraft}^{12}$ found that videoanimations were more effective than comicstrips for explaining a medical treatment, although both media were more effective than plain texts. The highest average increase in knowledge and attitude was held by the animations group. In this study, all the settings and players in the animations were also included in the comic strips. The only different was the voice in the animations. Comic strips apparently were less able to add to the respondents' knowledge and attitudes concerning the FTD compared to the booklet. Perhaps the setting of Batak's pictorial in the comic strips was not pleasing or binding to the teens' emotions or ethnic experiences. This indication was shown in the Batak and Java teens.

Effectiveness of nutritional education by means of animations, comic strips and booklet media: The effectiveness of media to deliver nutritional education was measured in this study by computing the $\mathrm{N}$-gain score of respondents knowledge and attitudes, as shown in Table 6.

Table 4: Averages, standard deviation, minimum, maximum of respondents's attitudes in the animations group, comic strips group and booklet group

\begin{tabular}{|c|c|c|c|c|c|c|}
\hline \multirow[b]{2}{*}{ Attitude } & \multicolumn{2}{|c|}{ Animations group } & \multicolumn{2}{|c|}{ Comic strips group } & \multicolumn{2}{|c|}{ Booklet group } \\
\hline & Before & After & Before & After & Before & After \\
\hline Average & 16.600 & 20.3 & 15.900 & 17.9 & 17.000 & 20.1 \\
\hline Standard deviation & 2.600 & 2.7 & 2.700 & 3.2 & 2.600 & 2.3 \\
\hline Minimum Value & 9.000 & 15.0 & 9.000 & 12.0 & 10.000 & 15.0 \\
\hline Maximum value & 21.000 & 25.0 & 21.000 & 25.0 & 24.000 & 23.0 \\
\hline $\mathrm{N}$ & 45.000 & 45.0 & 45.000 & & 45.000 & \\
\hline$p$ value & 0.001 & & 0.001 & & 0.001 & \\
\hline Average difference & 3.700 & & 2.000 & & 3.100 & \\
\hline
\end{tabular}

Table 5: The average difference of the knowledge and respondents' attitude in the animations group, comic strips group and booklet group

\begin{tabular}{|c|c|c|c|c|}
\hline Variables & Animations group & Comic strips group & Booklet group & p-value \\
\hline Knowledge & 8.53 & 5.76 & 5.74 & 0.001 \\
\hline Attitude & 3.71 & 2.00 & 3.08 & 0.001 \\
\hline
\end{tabular}

Table 6: N-Gain score in the animations group, comic strips group and booklet group

\begin{tabular}{lll}
\hline Variables & Animations group & Comic strips group \\
\hline Knowledge & 0.42 & 0.27 \\
& Moderate & Looklet group \\
Attitude & 0.42 & 0.28 \\
& Moderate & 0.23 \\
Low \\
\hline
\end{tabular}


The result of $\mathrm{N}$-Gain calculations by 0.42 (moderate category) shows that the effectiveness of animations is higher or better compared to that of comic strips and booklets in terms of increasing knowledge and improving attitude. Although the N-Gain score of the booklet group was categorized as moderate, the $\mathrm{N}$-Gain score of the animations group remained higher.

The effectiveness of animations as media for nutritional education concerning the FTDL shows that an animation was better and more attractive due to its visible videos and audible voices. Audio-visual media can add to one's understanding and effectively increase knowledge.

Similar results were reported by Yuliatii ${ }^{20}$ who showed the $\mathrm{N}$-Gain of ethnic to be 0.472 (moderate) and demonstrated that the effectiveness of videos was higher or better when compared to that of comic strips. The use of entertainment counseling on balanced nutrition with female teens by video is effective to increase their understanding concerning nutritional fulfillment.

The animation compiled in this study is based on Batak culture (one of the tribes in North Sumatra Province). The story is composed using female characters from a Batak tribe. Cultural narratives that characterize can result in changes in health behavior but are underutilized ${ }^{21}$. Animations can explain complicated content and can facilitate better understanding ${ }^{22}$. Important analysis of developing multimedia needs to be conducted to produce greater effectiveness ${ }^{23}$. The advantage of animation is that it can be used as a source of independent learning. Future challenges are the creation of animation regarding the $1000 \mathrm{HPK}$ for young women as a second window of opportunity and for women of childbearing age and women who are pregnant, especially in the first trimester of pregnancy.

The expected result of the animations media is a willingness to alter eating habits to fulfill nutritional requirements with substances related to the FTDL. Such alterations require time that could be divided into three stages: knowledge; attitude; practice. Therefore, the animations must be improved in order to motivate female teens, fertile women and pregnant women to alter their attitudes toward better support during the FTDL. Training using cellular media, such as animations, offers as an effective resource for future education, as well as a bridge to provide knowledge in remote areas or places of limited access for direct training ${ }^{24,25}$.

\section{CONCLUSION}

There was an increase in the knowledge and improvement of the attitudes of the respondents following the interventions using animations, comic strips and booklets.
The increase in knowledge is an important aspect to improve the attitudes of these respondents concerning the FTDL. Animations were more effective for increasing the knowledge and improving the attitudes of the respondents than comic strips and booklets.

\section{SIGNIFICANCE STATEMENT}

This study has helped the researcher develop animations by a cultural approach as an education media concerning the importance of the first 1000 days of life (FTDL). Support for education concerning the FTDL could be improved by using animations media, especially for female teens, fertile women, pregnant women and breastfeeding mothers.

\section{ACKNOWLEDGMENTS}

The authors appreciate Poltekkes Kemenkes Republik Indonesia Medan as the funder of this study by a competitive fund. The authors than kall the female teens in the high schools in Lubuk Pakam, Deli Serdang, North Sumatra Province, Indonesia, for their cooperation and commitment as respondents during this study.

\section{REFERENCES}

1. Development Initiatives, 2018. Global Nutrition Report: Shining a light to spur action on nutrition. Development Initiatives Bristol, UK, Pages: 11.

2. Kementerian Kesehatan, 2018. Hasil Utama Riskesdas 2018. Badan Penelitian dan Pengembangan Kesehatan.

3. Kementerian Kesehatan Ri, 2013. Riset Kesehatan Dasar. Badan Penelitian dan Pengembangan Kesehatan, Jakarta pp: 213-214.

4. WHO., 1989. Global Nutrition Targets 2025: Stunting Policy Brief. World Health Organization, Geneva.

5. Ramayulis, R. and S. Lwaningsih, 2018. Stop Stunting Dengan Konseling Gizi. Persatuan Ahli Gizi Indonesia Jakarta, Indonesia pp: 9-10.

6. Sudargo, T., T. Aristasari and A. 'Afifah, 2018. 1000 Hari Pertama Kehidupan. UGM PRESS, Depok, Indonesia Pages: 216.

7. Prasetyoputra, P., S. Irianti, M.J. Herman, R.S. Handayani and A. Yunianto etal,, 2013. Riset Kesehatan Dasar 2013-Riskesdas [Baseline Health Research 2013 - Riskesdas]. National Institute of Health Research and Development, Ministry of Health, Republic of Indonesia. (In Indonesian).

8. Djauhari, T., 2018. Gizi dan 1000 HPK. J. Ilmu Kesehatan Kedokteran Keluarga, 13: 125-133. 
9. S.P. Sativa, 2016. Tingkat penerimaan media audio-visual pendidikan gizi tentang pedoman gizi seimbang pada siswa sekolah dasar. Bachelor Thesis, Institut Pertanian Bogor

10. Farinella, M., 2018. The potential of comics in science communication. J. Sci. Commun., Vol. 17, No. 1, 10.22323/2.17010401

11. Matt, F., 2015. One Giant Leap: A Review of Unflattening. The Comics Grid: J. Comics Scholarship, Vol. 5, No. 1 10.5334/cg.ax

12. Kraft, S.A., M. Constantine, D. Magnus, K.M. Porter and S.S.J. Lee et al., 2016. A randomized study of multimedia informational aids for research on medical practices: Implications for informed consent. Clin. Trials, 14: 94-102.

13. Ma'munah, M., 2015. Pengaruh Pendidikan Kesehatan Dengan Booklet Terhadap Pengetahuan Ibu Laktasi Di Wilayah Kerja Puskesmas Ciputat Timur. Undergraduate Thesis, Institutional Repository UIN Syarif Hidayatullah Jakarta

14. Apriani, A., M.L.F. Kumalasari, 2015. Pengaruh pendidikan kesehatan dengan booklet terhadap pengetahuan dan sikap tentang deteksi dini kanker payudara pada wus di surakarta jawa tengah. J. Kesehatan Kusuma Husada, 6: 33-37.

15. Zulaekah, S., 2012. Pendidikan gizi dengan media booklet terhadap pengetahuan gizi. Kemas: J. Kesehatan Masyarakat, 7: 127-133.

16. Lanita, U., T. Sudargo and E. Huriyati, 2017. Pengaruh pendidikan kesehatan melalui short message service (sms) dan booklet tentang obesitas pada remaja overweight dan obesitas. J. Gizi Klin. Indonesia, 12: 36-44.

17. Angelina C.F, D.D. Nuryani and D. Elviyanti, 2019. Efektifitas pemanfaatan media gambar bergerak dan video animasi terhadap peningkatan pengetahuan dan sikap ibu tentang gizi seimbang pada balita. J. Kesehatan, 10: 181-186.
18. Saban, S., 2017. Efektifitas media video dan leaflet terhadap pengetahuan tentang anemia siswi sman 2 ngaglik sleman. Bachelor Thesis, Universitas 'Aisyiyah

19. Waryana, 2016. Promosi Kesehatan, Penyuluhan, dan emberdayaan Masyarakat - Waryana. Nuha Medika Yogyakarta, Pages: 408.

20. Yuliati, Y., D. Pramiadi and T. Rahayu, 2014. Efektivitas penggunaan edutainment konseling gizi terhadap pemahaman pemenuhan gizi seimbang pada remaja putri. J. Pendidikan Matematika Sains, 2: 160-167.

21. Murphy, S.T., L.B. Frank, J.S. Chatterjee, M.B. Moran, N. Zhao, P.A. de Herrera, L.A. Baezconde-Garbanati, 2015. Comparing the relative efficacy of narrative vs nonnarrative health messages in reducing health disparities using a randomized trial. Am. J. Public Health, 105: 2117-2123.

22. Hwang, I., M. Tam, S.L. Lam and P. Lam, 2012. Review of use of animation as a supplemetary learning material of physiology content in four academic years. Electron.J. E-Learning, 10: 386-377.

23. Aronson, I.D., L.A. Marsch and M.C. Acosta, 2012. Using findings in multimedia learning to inform technology-based behavioral health interventions. Behav. Med. Pract. Policy Res., 3: 234-243.

24. Nilsson, C., B.L. Sørensen and J.L. Sørensen, 2014. Comparing hands-on and video training for postpartum hemorrhage management. Acta Obstet. Gynecol. Scand., 93: 517-520.

25. Liu, C. and P. Elms, 2019. Animating student engagement: The impacts of cartoon instructional videos on learning experience. Res. Learn. Technol., Vol. 27, 10.25304/rlt.v27.2124. 